\title{
ARCHITECTURE AND MATERIALS IN THE FIRST HALF OF THE 20TH CENTURY IN ITALY
}

\author{
G. BERNARDO ${ }^{1} \&$ L. PALMERO IGLESIAS ${ }^{2}$ \\ 'Department of European and Mediterranean Cultures, University of Basilicata, Italy. \\ ${ }^{2}$ Department of Architectural Constructions, Technical University of Valencia, Spain.
}

\begin{abstract}
The architecture and the materials used in the constructions have always been the symbol of the culture and progress of a people. Each historical period can be described in its complexity through the architectural heritage. The built environment is really an extraordinary testimony of the creativity and intelligence of humankind, of its enormous possibilities but also of its limitations as well as of a certain sensitivity and world view. This paper illustrates a multidisciplinary and historical-critical study of the main architectural trends in Italy in the first half of the 20th century: from the Futurism of the early 20th century to the rationalism of the fascist period. The work is focused on the role of the architecture in the socio-economic development of a country and on the complex relationship between materials innovation and architecture, which originates even today the debate between modernity and tradition. The results highlight the outstanding importance in the evolution of the different ways of conceiving architecture. It can be just a Utopia as in the Futuristic architecture, a drive towards a better world which will be able to meet the growing needs of an ever-changing world, or rise to fulfil the function of science and art through the innovative use of new materials and manufacturing technologies.

Keywords: architectural heritage, autarkic materials, ceramic materials, Futuristic architecture, Italian rationalism, Litoceramica, natural stone, Novecento Movement, reinforced concrete.
\end{abstract}

\section{INTRODUCTION}

Since antiquity, the architecture and materials used in constructions have been the mirror of the culture and progress of a people. The built environment is really an extraordinary testimony of the creativity and intelligence of humankind, of its enormous possibilities but also of its limitations as well as of a certain sensitivity and world view. Each historical period can be described with its architectural heritage.

This paper illustrates a multidisciplinary and historical-critical study of the main architectural movement in Italy in the first half of the 20th century. The work is part of a research activity aimed at studying the evolution of architecture and building materials in Italy and Spain in the 20th century, involving the Department of Architectural Constructions of Technical University of Valencia and the Department of European and Mediterranean Cultures of the University of Basilicata.

This paper describes the revolutionary path of Italian architecture, going from the Mannerist eclectic style of the early 20th century to the visionary Futuristic avant-garde, from the synthesis of modernity and tradition of the Novecento Movement to the sublime rationalism of Pier Luigi Nervi.

\section{THE FIRST TWO DECADES OF THE 20TH CENTURY}

At the beginning of the 20th century, Italy had a slower progress than the rest of Europe with very strong geographical disparities. The nascent industry developed in the major cities of northern Italy, Turin, Genoa and Milan, which were provided with electricity from hydroelectric plants. The population of these three cities increased dramatically due to emigration from the countryside 
of people living in absolute poverty. Even Rome in Central Italy, proclaimed capital of the country in 1870, attracted thousands of people who considered it the fulcrum of the progress.

Southern Italy was not involved in the process of industrialization. The gap between south and north in terms of social and economic conditions deepened, resulting in the issue known as 'southern question' still relevant today.

Italian architecture of the early 20th century was stifled by the general diffusion of the eclecticism, which assigned primary importance to the traditional decorative value of the detail rather than to the construction in its entirety (De Seta [1], Benevolo [2]). The use of different architectural styles belonging to previous historical periods was widespread with a predominance of oriental or Egyptian suggestions.

In 1911, several Italian architects presented, at the exposure held in Rome to commemorate the fiftieth anniversary of the Unification of Italy, a series of temporary and permanent buildings large enough to surprise the visitor with a strong eclectic component. These structures were described with emphatic and enthusiastic tones in the periodic 'Rassegna Illustrata della Esposizione del 1911', published every two weeks from June 1910 to December 1911. Figure 1 shows one of the covers of the magazine that has a crucial importance to understand the political and cultural climate of Italy of that time (IDEA [3]). The magazine provided detailed and valuable information on the progress of the started or completed works and regularly recorded the many initiatives undertaken during the celebrations for the fiftieth anniversary of the Unification of Italy with their motivations and in their multiple aspects.

Both the structural component and decorative elements were built with natural stones and bricks. The use of new materials, i.e. reinforced concrete and steel, was limited to a very few cases relating to the construction of important industrial establishments, commercial galleries or large bridges (Hellebois et al. [4]). New materials had much higher costs than traditional ones and it was extremely difficult to find workers who were able to put them in place. Moreover, the technology of reinforced concrete, an innovative composite material combining in a synergistic way the compressive strength of concrete with the tensile strength of steel reinforcing bars, was almost exclusively based on the production of precast elements protected by patents (AITEC [5]).

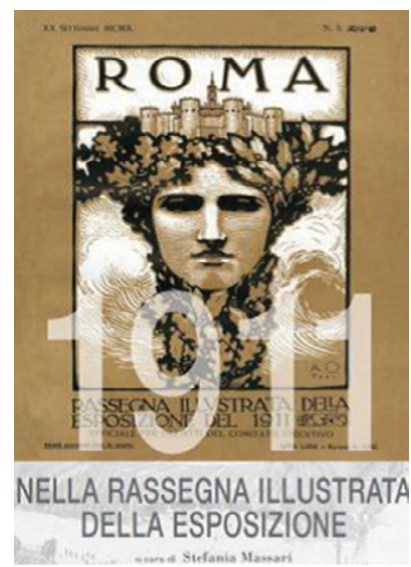

Figure 1: One of the covers of the periodic 'Rassegna Illustrata della Esposizione del 1911' (Source: IDEA [3]). 
The war period for Italy started with the first campaign of Libya from 1911 to 1912 and it went on with the Great World War, between May 1915 and November 1918.

The second decade of the 20th century was one of the darkest periods in the history of Italy with a real collapse of the development that led to the terrible crisis of industry and agriculture in October 1922. During this period of terrible crisis, the Futurist movement led a real revolution in the field of architecture, influencing all its evolution in the 20th century.

\subsection{The Futurist Architecture}

Filippo Tommaso Marinetti published the Futurist Manifesto in the newspaper Le Figaro of Paris on 20 February 1909. This declaration of intentions marked the beginning of one of the most important avant-garde, which will last about three decades, profoundly marking the history of the Italian culture. The Futuristic aesthetic was based on the dynamism of the progress and on the myth of the speed and machine that could be achieved by means of a radical and timely renewal. The chilling tribute to war of the Manifesto, 'We will glorify war, world's only hygiene', was an encouragement to the break and the revolution, a last resort to renew, in opposition to 'the thoughtful immobility, the ecstasy and the sleep' of the Italian intellectual climate of the time (Lista [6]).

In 1914, the architect Antonio Sant'Elia (1888 -1916, died in war), captivated by the ideas of Marinetti, published the Manifesto of Futurist, determining a real turning point in the Italian architecture (Lista [6], Caruso [7]).

The Manifesto began with a ferocious invective against the eclectic style in vogue at that time which was described as 'an architectonic prostitution', 'a moronic mixture of the most various stylistic elements', 'a vacuous stylistic exercise', 'a jumble of ill-mixed formulae' and 'a grotesque anachronism' used to disguise a traditionalist construction of bricks and stone as a modern building. In the following, it stated that the architecture should meet the needs of modern man by building with the new materials the Futuristic City and House, according to a new ideal of beauty that meets the aesthetic taste of modern man for the light, the practical, the ephemeral and the swift. The oblique and elliptic lines, symbols of the modernity and dynamism, should be used in substitution of the perpendicular and horizontal lines of the monumental, funereal and commemorative styles of the past. The 'superb grace of the steel beam' and the 'delicacy of reinforced concrete' should be preferred to the bulky appearance of marble. Moreover, there was a preference for the verticality according to the new-rise buildings, which were spreading in America. It also proclaimed the abolition of any decorative elements and the aesthetic value of the construction depended entirely on the use and original arrangement of the materials, which should be bare or 'violently' coloured.

Some parts of the Manifesto of Futuristic Architecture are reported as follows in order to fully understand its revolutionary impact in the way of conceiving the architecture:

Futurist architecture is the architecture of calculation, of audacious temerity and of simplicity; the architecture of reinforced concrete, of steel, glass, cardboard, textile fibre, and of all those substitutes for wood, stone and brick that enable us to obtain maximum elasticity and lightness (....). We feel that we are no longer the men of cathedrals, palaces and the podiums, but we are the men of great hotels, railway stations, immense streets, colossal ports, covered markets, luminous arcades, straight roads and healthy demolitions. We must invent and rebuild ex novo the Futurist city like an immense and tumultuous building site, agile, mobile and dynamic in all its parts; and the Futurist house must be like a giant machine. 
The lifts no longer have been hidden away like tapeworms in the niches of stairwells; the stairwells themselves - made useless - must be abolished, and the lifts must climb along the façades like serpents of steel and glass. The house of concrete, glass and steel, stripped of paintings and sculpture, rich only in the innate beauty of its lines and relief, extraordinarily ugly in its mechanical simplicity, higher and wider according to need rather than the specifications of municipal laws. It must soar up on the brink of a tumultuous abyss: the street, which will no longer stretch like a doormat at ground level, but it will sink into the ground for several floors which will host the metropolitan traffic and will be linked up for necessary interconnections by metal gangways and moving walkways. (Caruso [7])

The 'audacious temerity' of Futurist Architecture led to the graphical representation of real Utopias that were visions of the modern world including the entire city on an urban scale as well as the single building. It ranged from small residences to large infrastructure, such as railway stations or airports, power plants, industries and theatres.

Sant'Elia was the most important exponent of the movement. He drew the new constructions only in perspective providing a captivating vision and evocative of modern Futuristic city, which remains limited to only theoretical level. Figures 2 and 3 show the drawings of a case study of a power plant and the new railway station of Milan, respectively (Costanzo and De Propis [8]). Nevertheless, the work of Sant'Elia had an extraordinary influence in the process of renewal of architecture in Italy and his works, though unrealized, are worthy of attention in the same way of real existing buildings.

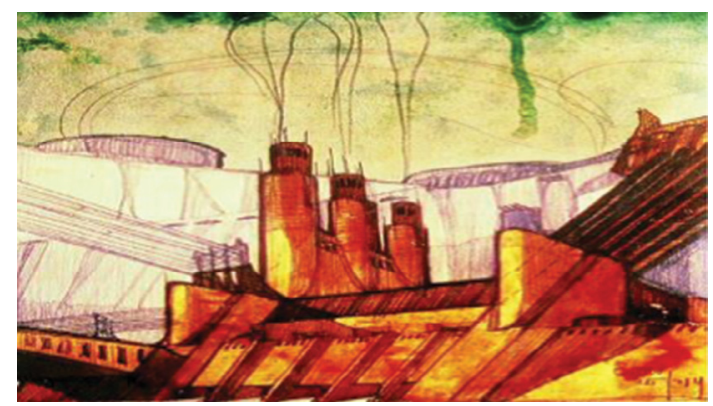

Figure 2: Case study of a power plant. Antonio Sant'Elia, 1914 (Source: Costanzo and De Propis [8]).

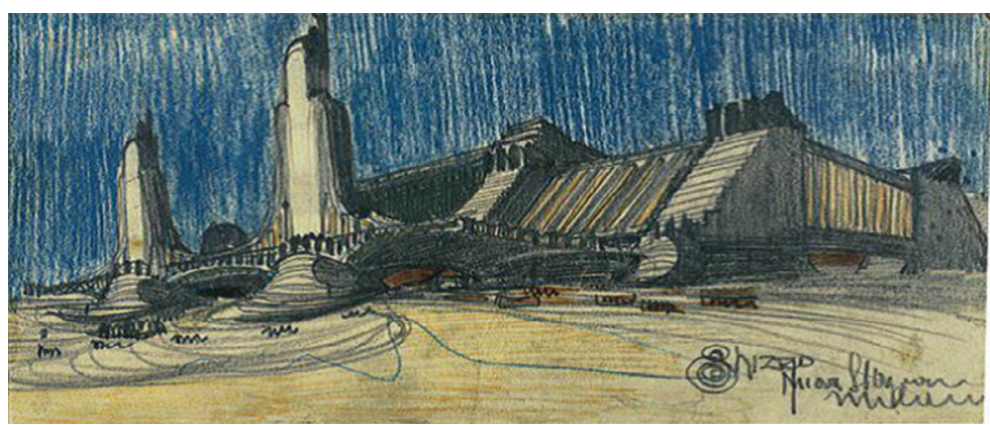

Figure 3: New railway station of Milan. Antonio Sant'Elia, 1913 (Source: Costanzo and De Propis [8]). 


\section{THE 20 YEARS OF FASCIST REGIME}

The fascist regime of Benito Mussolini lasted from 1922 to 1943. Mussolini proclaimed himself 'Duce', from Latin word 'dux' that means warlord. This period was characterized by huge contradictions related to both the Duce's controversial personality and his ambitious political project. He could have been a great politician and he was a merciless dictator instead. His political challenge was to modernize Italy to make a great nation and to revive the former glory of the past by imposing the return to the Italian valour and traditions.

The construction industry had a great development under the fascist regime. The modernization of the country required the construction of new public buildings, new social housing and road and rail infrastructures. Mussolini commissioned a series of works that improved the aesthetic and functional value of entire urban areas and the living conditions in some regions of the country. The cinematographic institution 'Istituto LUCE' (L'Unione Cinematografica Educativa), created in 1924 for educational and informative film distribution, documented the construction phases of several works used as propaganda of the regime.

In this period of great vitality in the sector of construction, architecture had to face the challenge of identifying a style that could mediate between modernity and tradition, functional efficiency and aesthetic value of the construction, new materials and technology and vernacular uses of traditional materials. This challenge today is still very timely in a country like Italy which is rich of cultural heritage of extraordinary beauty.

The construction sector was also deeply influenced by the autarkic policy of the fascist regime aiming to make the nation self-sufficient, especially since 1936, when the Society of Nations sanctioned Italy for invading Ethiopia.

In this coercive situation, the fascist regime promoted the development of national materials, termed also 'autarkic materials' as they were manufactured by Italian raw materials and technologies.

The bricks and ceramics by coating were the most widely used autarkic materials due to a series of concomitant factors (Augelli [9]). They were obtained by raw materials on the national territory through advanced technologies which were able to mass-produce ceramic materials with different sizes and high and controlled qualities. The Italian ceramic industry was equipped with the best machine tools for forming through wire-drawing and extrusion and with advanced ovens in which it was possible to control the temperature for the benefit of the uniformity of firing and product quality (Sersale [10]).

The extensive use of bricks was due to the attitude of fascism towards the new technology of reinforced concrete, which at that time was spreading across Europe. Especially at the beginning, the regime did not have a negative attitude towards this new technology which it recognized to be higly advantageous so it updated the sector regulations on several occasions (Sollazzo [11]). However, the reinforced concrete required a large amount of steel that was an importing material. Consequently, the traditional masonry was preferred to reinforced concrete, also because it was considered particularly suitable to celebrate the glories of the regime by realizing monumental buildings that recalled the majesty of Italian old buildings.

By the end of thirties, the regime took a drastic behaviour. First, in 1937, it introduced an obligation to use ordinary masonry in the construction of buildings up to five floors. Successively, in 1939, with the Royal Decree-Law n. 1326, it imposed a total ban on the use of reinforced concrete in all types of buildings with the exception of those promoted by the Ministries of War, Navy, Aeronautics and Telecommunications (Sollazzo [11]). This law 
remained in force in Italy until 1947 when it was abrogated by the Decree of the Provisional Head of the State n.183 (GURI [12]).

In the constructions promoted by the regime, the frame structure in reinforced concrete or in steel with outer walls in bricks was utilized (Sollazzo [11]). This determined the use of ceramic materials by coating to which the task of protecting the skeleton of reinforced concrete or steel and hiding the aesthetic heterogeneity of the beams-pillars-walls system was given.

In addition to emergency reasons determined by the economic situation of Italy and to the fascist propaganda in favour of the use of traditional materials belonging to the cultural heritage of the Italian people, two objective reasons lead to the widespread use of ceramic materials. They ensured hygiene and the cleaning as well as the harmony of colours of the interior and the durability of exterior facades (Augelli [9]).

Among the many ceramic materials that were patented in this period in Italy, the 'Litoceramica Italklinker' deserves a special mention (Castagnoli [13], Minnucci [14]). This material belongs to the category of ceramic products with silicate and vitrified structure. It was produced by the industrial plant Ceramics Piccinelli of Bergamo by a mixture based on vitrifiable kaolinitic clays and natural and calcined feldspar rocks (basalts and porphyry) to which a series of catalysts in solution was added (sodium stearate, salts of humic acid, salts of oxalic acid, potassium pyrogallate, sodium silicate, magnesium sulphate, aluminium chloride and ammonium nitrate) (Minnucci [14]). The firing process was carried out at elevated temperatures, between $1200^{\circ}$ and $1300^{\circ} \mathrm{C}$, for several hours. This led to the formation of a high percentage of amorphous phase during the greification process (Minnucci [14]). The obtained product had a compact, homogeneous and waterproof structure, high resistance to freeze-thaw cycles and high mechanical and chemical resistance. The reduced size of the format guaranteed a modest shrinkage and deformation during the firing. The colour varieties were very large (Castagnoli [13]). The material was extruded and the laying surface was corrugated to improve the adhesion of the mortar (Castagnoli [13]). The properties of the Litoceramica Italklinker were comparable to those of the natural stones with respect to which it had the advantage of being cheaper (Castagnoli [13], Minnucci [14]).

The compulsory use of autarkic materials profoundly conditioned the Novecento Movement and the Italian rationalism that developed in Italy during the fascist period.

\subsection{The Novecento Movement}

In 1922, a group of seven artists (Anselmo Bucci, Leonardo Dudreville, Achille Funi, Gian Emilio Malerba, Piero Marussig, Ubaldo Oppi and Mario Sironi) founded in Milan the Novecento Movement. According to the need of the 'return to order' that followed the First World War, they rejected European avant-garde art and wished to revive the tradition of Italian painting in the classical manner (De Seta [1], Tentori [15]). The name of the movement (which means 1900s) was a deliberate reference to great periods of Italian art in the past, the Quattrocento and Cinquecento (1400s and 1500s).

Right from the start the movement was a propaganda instrument of the Mussolini's fascist regime whose rhetoric was founded on the exaltation of the glorious past of the Italian people and their old customs and traditions. In 1926, the first exhibition of the Novecento's artists was held in Milan in the presence of Mussolini. In the opening speech of the exhibition, he said: 
The Novecento's artists do not refuse and must not refuse any experience and no attempt; indeed, almost everyone has lived the Futuristic experience, but they intend to be and to represent something for themselves. It cannot make a great nation with a little people (....) It cannot govern ignoring the art and artists; Art is an essential manifestation of the human spirit (...). I declare that it is far from me the idea to encourage anything that might look like the art of the state. The art belongs to the individual realm. The State has only one duty: to not sabotage it, to give human conditions to the artists, to encourage them from the artistic and national standpoints. (Tentori [15])

These sentences highlight the extraordinary political vision of Mussolini about the strategic role of the government in the economic progress and in cultural evolution of a nation. The history has then shown that there was not consistency between his words and deeds, and Italy under his power lived in a climate of bloody repression and terror.

Numerous exponents of all areas of art and culture joined the Novecento Movement because of the endemic spirit of condescension to the power that has always characterized the Italian intellectual class.

The Novecento's architects maintained the need for change and modernity of Futurism and the firm stance against the eclectic style of the beginning of the century as well. They reconciled the modernity with the tradition through a simplification of the classic styles of those from whom they took the harmony of the composition and the purity of form.

Giovanni Muzio (1893-1982) was the most important architect of the movement. Muzio's architecture finds references in Lombard neoclassicism of the 19th century and at times it is inspired by 'metaphysics' of Giorgio De Chirico, resulting in constructions of monumental appearance (Tentori [15]). Between 1919 and 1922, he realized what he himself considered a manifesto work: the so-called Ca' Brutta via Moscova in Milan. This six-storey residential complex, shown in Fig 4 ([16]), with a structure in reinforced concrete stands on an original green area of the city and identifies an entire block. Figure 5 illustrates its facades that are coated by travertine at the bottom, dark plaster in the middle part and antique stucco of Vicenza, based on lime and marble dust, at the top ([17]). Its construction caused a scandal and a great sensation, as a popular name in Lombard dialect was given to the building, which means 'Ugly House'. The use of the elements of the classical language was considered excessive and extravagant, in short 'a madness of an architect'.

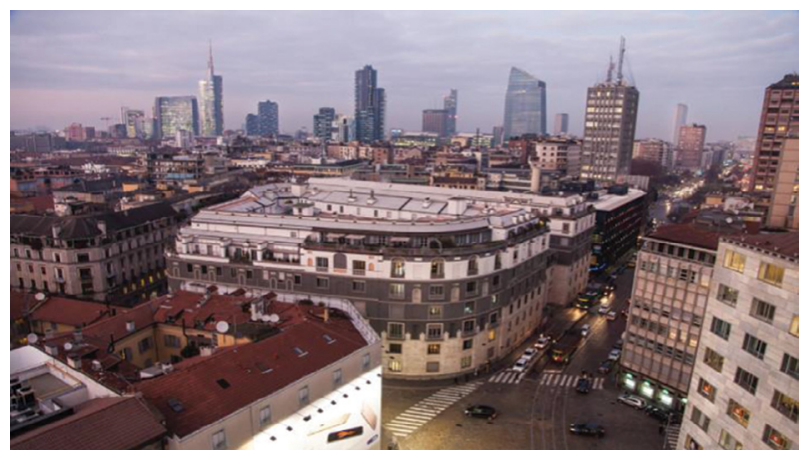

Figure 4: The entire block of the City of Milan identified by Ca' Brutta. Giovanni Muzio, 1919-1922 (Picture: Ray Banhoff). 


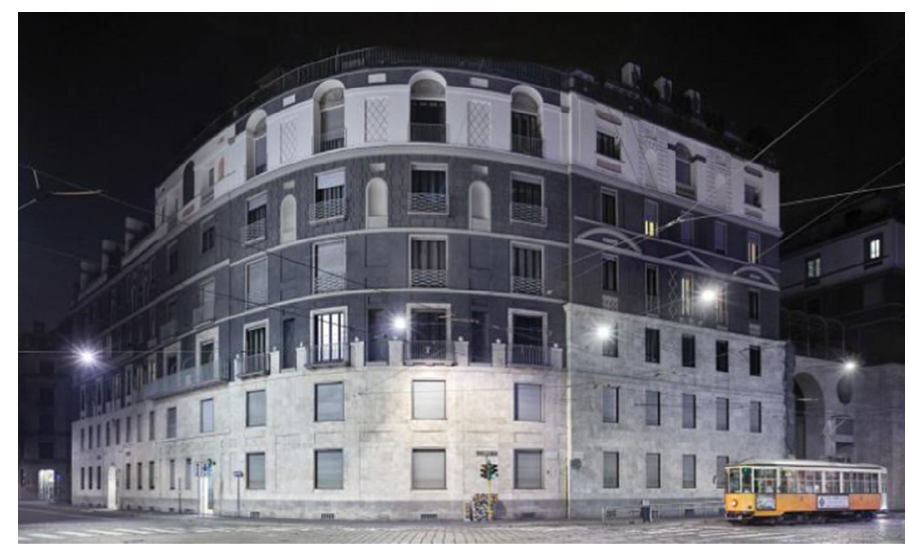

Figure 5: The facades of Ca’ Brutta. Giovanni Muzio, 1919-1922 (Picture: Luca Campigotto).

The originality of the language and the modern functional articulation of volumes also characterized Muzio's other works. Among these, the Palace of the Art, built during the years 1931-1932 within the Sempione Park of Milan, deserves a special mention. The building, shown in Fig. 6, has classical references that highlight its monumentality and belonging to the regime (ARTE FASCISTA [18]).

The Litoceramica Italklinker was used for the first time in the construction of this building (Castagnoli [13], Minnucci [14]). The palace has a large arcade in light white Litoceramica on the main facade and bearing walls with a thickness of just $15 \mathrm{~cm}$ in dark red Litoceramica, which collaborate with the frame structure of reinforced concrete (Castagnoli [13]).

The regime used the construction of the Palace of the Art to publicize the excellent qualities of this new autarkic material. Its compressive strength was nearly $120 \mathrm{MPa}$, six times higher than the common brick (Castagnoli [13], Minnucci [14]). The Litoceramica also had the important advantage of acting as coating, thanks to its aesthetic qualities, impermeability and durability. Figure 7 shows the visit of Mussolini during the construction of load-bearing brick walls of the Palace of the Art (Minnucci [14]).

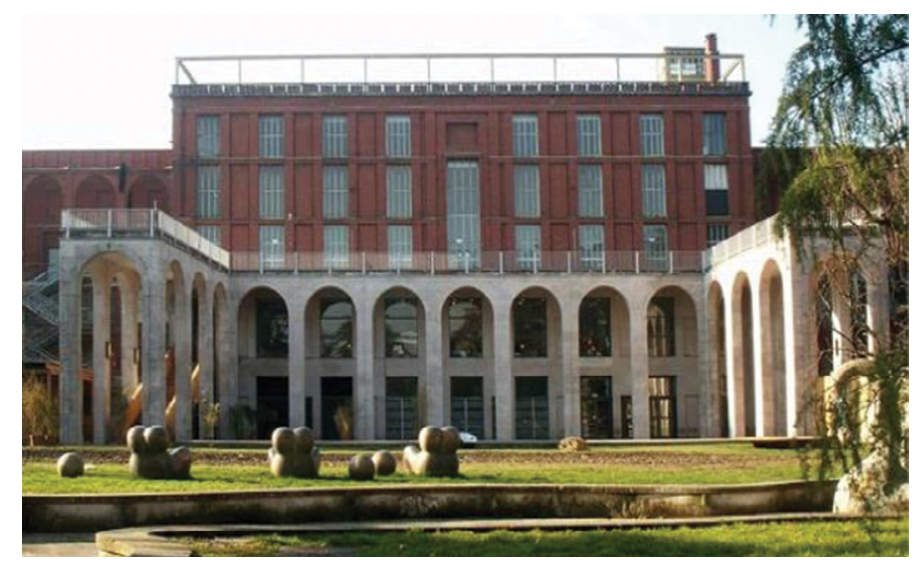

Figure 6: The Palace of the Art in Milan, Giovanni Muzio, 1931-1932. 


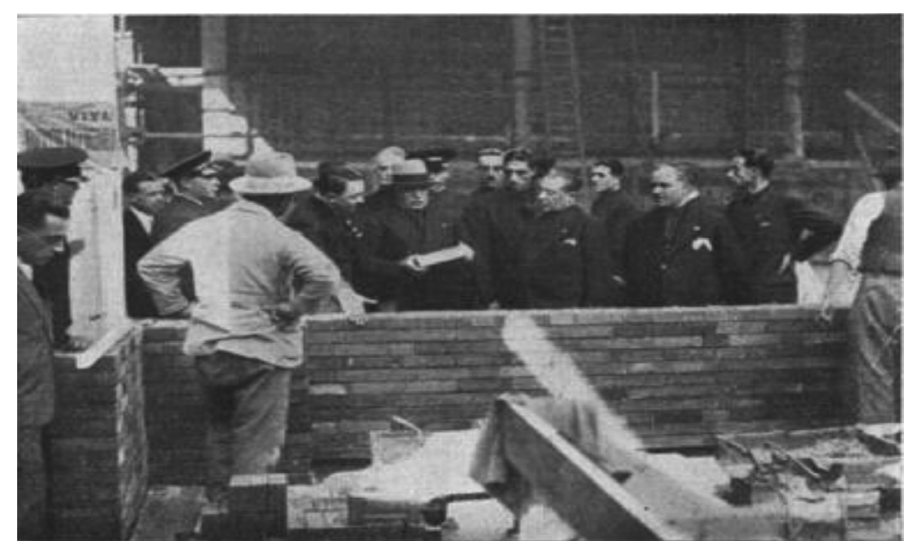

Figure 7: Visit of Mussolini during the construction of load-bearing walls of the Palace of the Art with Litoceramica Italklinker.

\subsection{The Italian rationalism}

In 1926, seven architects from Milan Polytechnic (Luigi Figini, Guido Frette, Sebastiano Larco, Giuseppe Terragni, Carlo Enrico Rava, Gino Pollini and Ubaldo Castagnoli who was subsequently replaced by Adalberto Libera) formed the so-called Gruppo 7, name probably chosen to emulate the famous group of seven painters of the Novecento Movement (De Seta [1], Benevolo [2], Tentori [15]).

The architects of the Gruppo 7 aimed to renew the architectural thinking of the period through the adoption of the rationalism that represented a new way to conceiving the architecture in keeping with the theories of the European Modern Movement. The rationalism assigned to the architecture the role of satisfying the needs of the time, giving rise to a new aesthetic characterized by the rejection of ornament and decoration and by the pursuit of pure and essential forms which were able to express the function of the spaces. Materials and shapes became indissoluble in the rationalist architecture. The verticality and the purity of the shapes seem to be an inevitable consequence of the use of the technology of reinforced concrete that was increasingly evolving and consolidating across Europe, particularly in France and Germany.

The movement of Gruppo 7 gathered supporters increasingly and constituted itself as an official body, the Movimento Italiano per l'Architettura Razionale (MIAR), in 1930.

The Italian rationalist architects cohabited inside the MIAR with many controversies. The architects of the new generation harshly criticized the works of their older academic colleagues, which, to them to say, gave a distorted image of the new architecture because of the use of traditional materials and forms contaminated with neoclassical references. Indeed, the clashes between the Italian rationalist architects were inevitable. The rationalism was ontologically against all forms of traditionalism, while the Architecture of the State commissioned by the fascist regime had to meet the antithetical requirements of exaltation of both the modernity and the tradition of the Italian people.

The rationalist architects implemented the large programme of public works of fascist regime by giving each one his own interpretation of the new spirit of renewal of the rationalism and his own response to the needs of regime's propaganda and to the obligations imposed by the autarkic policy (Augelli [9], Sollazzo [12], De Simone [19]). 
Among the many rationalist architects who designed works that form part of the architectural heritage of the country today, Marcello Piacentini, Giuseppe Terragni and Pier Luigi Nervi can be mentioned to fully describe the various facets that rationalism had in Italy.

Marcello Piacentini (1880-1860), an architect and urbanist, is a controversial figure in the history of the Italian architecture because of his closeness to Mussolini (De Seta [1], Benevolo [2]). The rationalist style of Piacentini had the merit of having interpreted the classic architecture in a modern way, eliminating decorations and architectural details, drawing smooth walls, rounded arches, and simple and smooth frames (Tentori [15], De Simone [19]). His architecture has a solemn monumentality with the linearity of the prospects opening up in a metaphysical, suspended and unreal scenario. According to the regime's autarkic policy, Piacentini adopted the construction scheme reinforced concrete frame structure - brick outer wall and coated surfaces with typical natural stone of the Italian territory, such as travertine, tuff, 'peperino' (a magmatic rock of Central Italy) and Carrara marble.

Giuseppe Terragni (1904-1943) stood out for his ability to originally develop advanced solutions from other great European architects, chief among them Le Corbusier, and for the innovative use of reinforced concrete as well (De Simone [19]). His architecture is characterized by a play of solids and voids, where the linear structural component is visible and draws the facade. He argued that it was necessary to give an artistic emotion to the observer using open and closed spaces, and heavy and lightweight masses (Zevi [20]). Terragni's life and activity are closely connected to the city of Como, in the North of Italy, which during the fascist period was one of the most culturally and socially active cities. His most famous work is the Casîa del Fascio built in Como between 1932-1936. This building, shown in Fig. 8, describes the creative spirit of Terragni within the context of the rationalist vocabulary.

It is a perfect prism with the side $33.20 \mathrm{~m}$ long and $16.60 \mathrm{~m}$ high, which is inspired by the basic principles of the purism of Le Corbusier. The coincidence of structural module in reinforced concrete and spatial module hindered any classicist potential. The pulling back of the entrance and breaking up of the top make together with the use of glass materials satisfy the requirement of 'transparency' commissioned by the regime to propagandize the involvement of the people in the decisions of the fascist party.

The originality of the rationalist style of Terragni is highlighted also by the monument for the victims of the First World War built between 1931 and 1933 on the shore of Lake Como (Fig. 9). The monument is a stately construction in reinforced concrete with a height of $33 \mathrm{~m}$ and surface polished like a mirror, thanks to the coating in Serizzo granite and Nabresina marble. The monument evokes the modernity and the progress of the sketch 'Industrial building' by Antonio Sant'Elia (Fig.10), who was killed during the Great War near the City of Trieste. In the north side of the construction, there is a quotation by Sant'Elia: 'Either this evening in Trieste, or tomorrow in heaven with the heroes!'

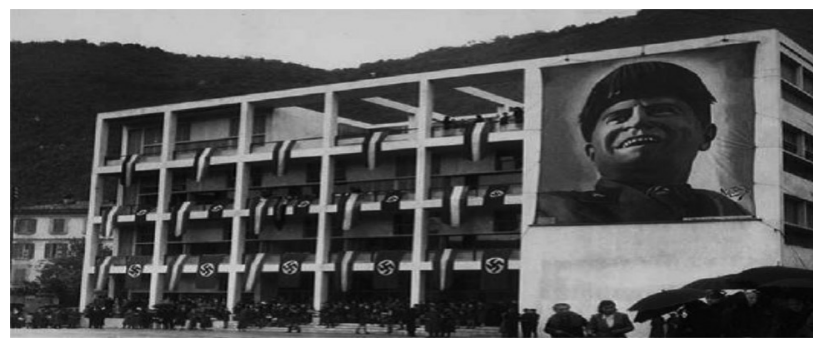

Figure 8: Casa del Fascio in the City of Como. Giuseppe Terragni, 1932-1936 (Source: Zevi [20]). 


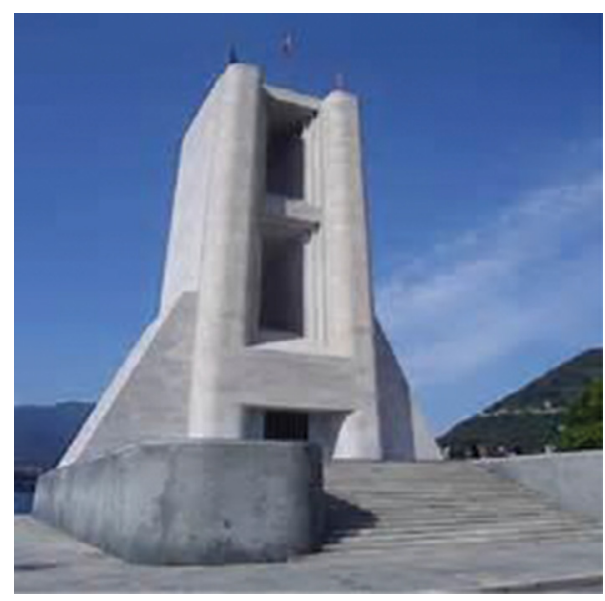

Figure 9: Monument to the Fallen of the First World War, Como Lake. Giuseppe Terragni, 1931-1933 (Source: http://www.portaledicomo.it Monumenti [21]).

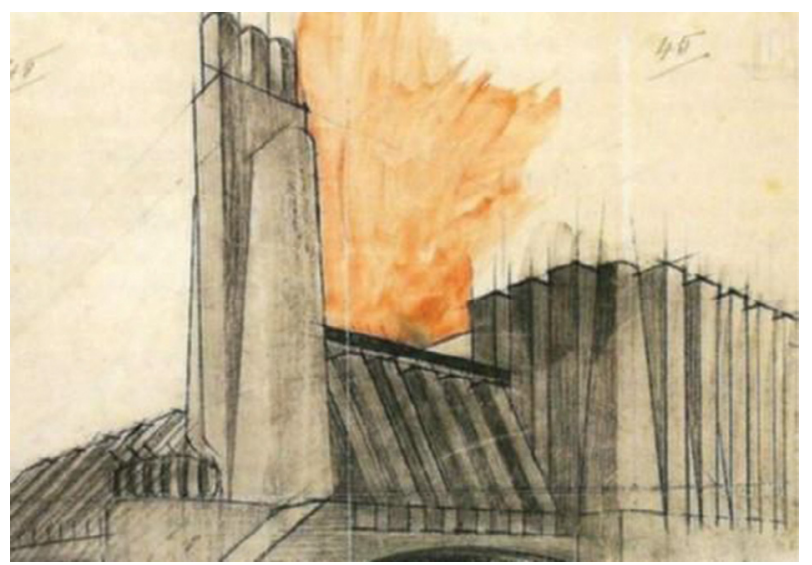

Figure 10: Industrial building. Antonio Sant'Elia, 1913 (Source: Pampaloni and Verdone [22]).

Pier Luigi Nervi (1891-1979) graduated in civil engineering at Bologna in 1913 and, after an initial period of training in the technical office of a construction company, he founded his own firm in 1920. The dual role of designer and builder together with the choice of reinforced concrete as construction technique contributed to make him an extraordinary figure in the engineering and architectural scene of the 20th century. All his works were characterized by an engineer's audaciousness, an architect's imagination and a builder's practicality (De Simone [19]). The use of reinforced concrete determined the distinguishing features of his architecture. The limits imposed by the square forms were overcome by curvilinear structures built through innovative technology solutions, whose static behaviour was often evaluated on laboratory scale models. The Nervi's architecture led to believe that any type of shape could be obtained with the use of reinforced concrete. 'Concrete is a living creature which can adapt itself to any form, any need, any stress' - it is one of the most suggestive and famous quotations of Nervi who was also a great professor and an extraordinary author of technical books.

During the fascist period, Nervi built his first great works and he soon became famous both in Italy and abroad. In the regime's propaganda, he became the symbol of a continuum 
between the glorious architectural past of Italy and the progress of the time, a perfect synthesis of the Mussolini's challenge to combine modernity and tradition.

His first major building was the Municipal Stadium in Florence (1930-1932), committed by the regime in memory of the fascist hero Giovanni Berta. The construction is characterized by the elegance and the strong visual impact of the cantilevered roof (Fig. 11) and exterior spiral staircases (Fig. 12). The roof is supported by curved cantilevered beams that are thickened at the bottom where bending forces are greatest and elegantly thinned at the top where loads decrease. This technical solution is a structural masterpiece that has also an

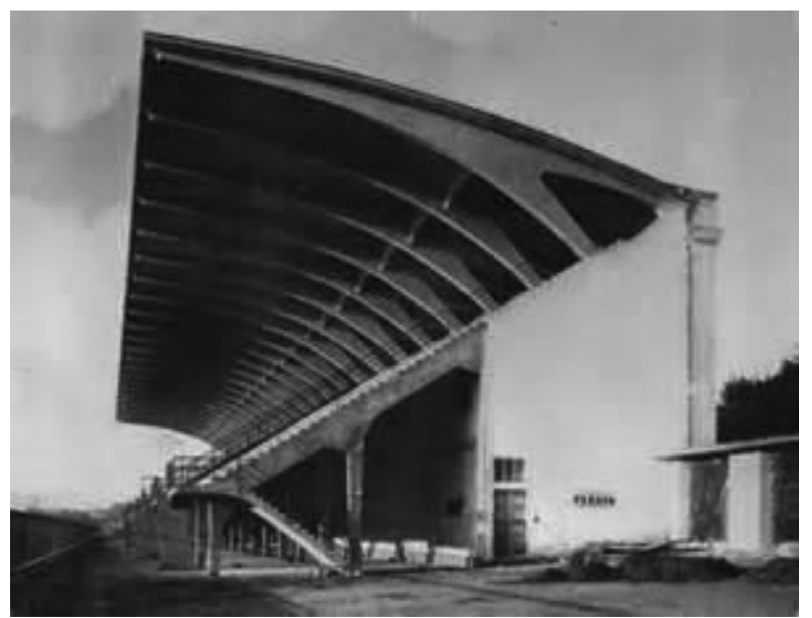

Figure 11: The cantilevered roof of the Municipal Stadium in Florence. Pier Luigi Nervi, 1930-1932 (Source: Nervi [23]).

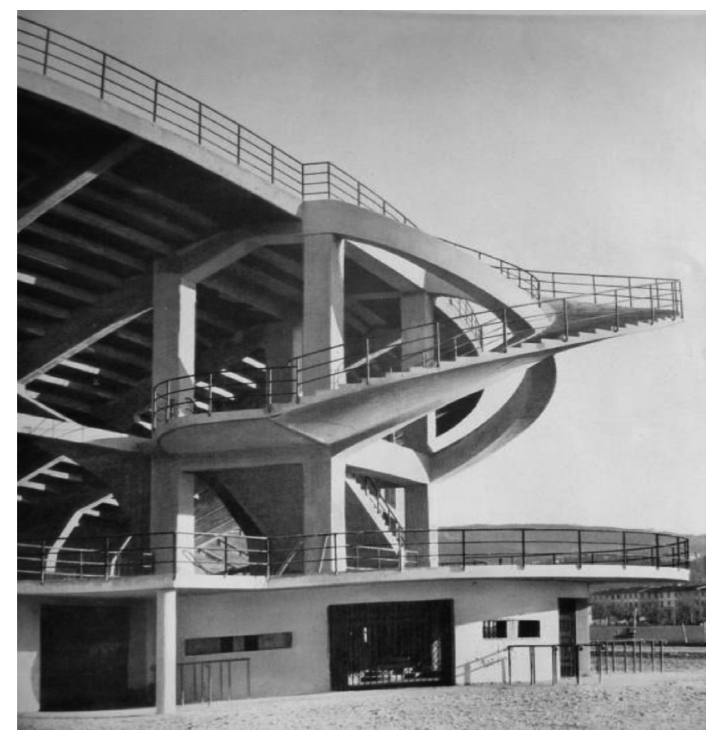

Figure 12: The spiral exterior stairs of Municipal Stadium in Florence. Pier Luigi Nervi, 1930-1932 (Source: Nervi [23]). 
outstanding teaching value. The spiral staircases are semicircular in section and supported by helical beams. They are a structural sculpture inspired by the soft flow of the crowd of spectators to the outside.

Between 1935 and 1940, Nervi built eight great hangars for the Italian air force at Orvieto and Orbetello in Central Italy. For these constructions, Nervi designed an audacious geodetic roof composed by a frame of intersecting arches, shown in Fig. 13. The first two hangars were built using cast-in-place concrete, while the sixth ones were built with precast elements for the ribs, which were then connected on-site. All eight hangars were destroyed by bombing of German forces in 1944.

The hangars were also the first structure for which, in addition to static calculations, Nervi used a reduced scale model (Fig. 14) made at Milan Polytechnic by Guido Oberti (1907-2004) in order to check the validity of his own original structural conception in the

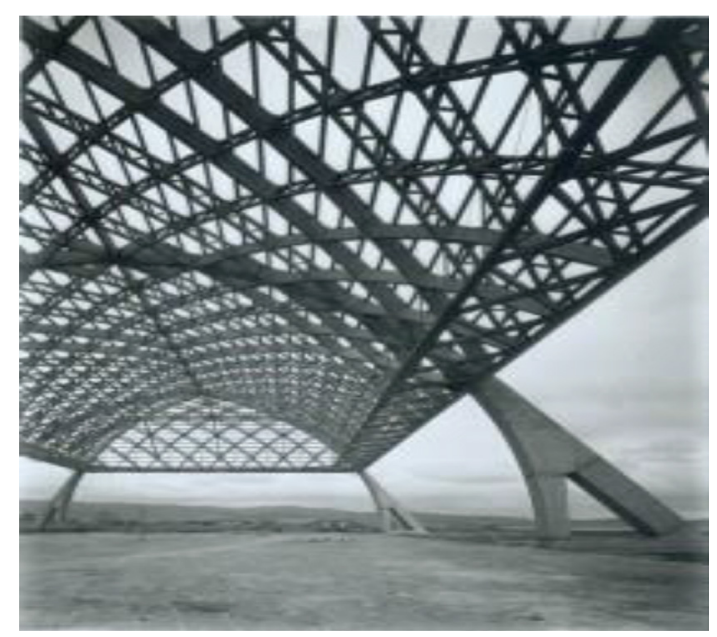

Figure 13: Geodetic structure of the hangars for the Italian air force. Pier Luigi Nervi, 1935-1940 (Source: Nervi [23]).

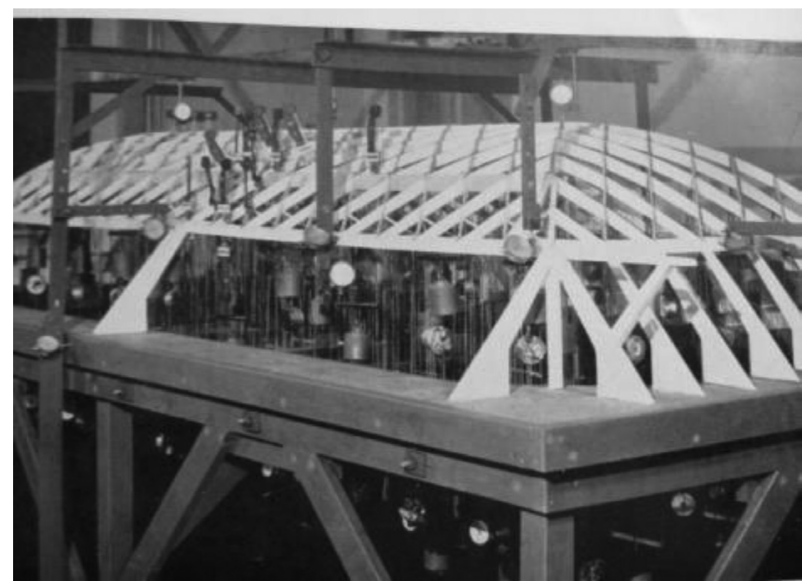

Figure 14: Scale model for the study of structural behaviour (Source: Nervi [23]). 
final phases of the project. He maintained this experimental procedure for most of his later works that restored the supremacy of Italy in the 'correctly building' finest, sound and durable constructions.

\section{CONCLUSIONS}

The first half of the 20th century has been one of the most interesting and lively periods of the Italian architecture.

The Futuristic Architecture marks a real breakthrough in the way of conceiving the architecture in Italy. It is redeemed from the sterile condition of arranging forms according to pre-established criteria to that of sublime synthesis of science and art, which transforms the world of things into a direct projection of the world of the spirit, according to the aesthetic taste and needs of modern man. The Futuristic vision with its revolutionary audacity also has the important merit of having laid bare the close relationship between materials and architecture that has always influenced all the architectural styles of each era. The abolition of any decorative elements proclaimed by the Futuristic Architecture highlights the key role of the materials on the aesthetic and functional quality of constructions. Moreover, the yearning for modernity and dynamism of Futurism introduces the captivating interest in the use of new materials which are able to fulfil the design requirements better than traditional ones.

The Novecento Movement offers an extraordinary synthesis between the desire of modernity and the return to the tradition imposed by the fascist regime by using the construction scheme reinforced concrete frame structure - brick outer wall and coating the facades with autarkic materials, namely natural stones and innovative ceramics such as the Litoceramica Italklinker.

The Italian rationalism is significantly affected by the autarkic policy and by the regime's propaganda. In place of reinforced concrete hindered by the regime, the rationalist architects use autarkic coating materials to obtain the linearity and purity of construction shapes.

With the works of Pier Luigi Nervi, an engineer and builder, the Italian rationalism reaches its highest expression, becoming sublime synthesis of the sinuous and curvilinear architecture of the Italian past and the Futuristic Utopias of the modern world. Nervi overcame the aversion of the regime towards the reinforced concrete by his innovations that make the new economic technology competitive even in a country like Italy which is poor in iron ore deposits. According to Nervi, the architecture is a synthesis of science and art and 'correctly building' means finding a logical and competitive solution to a series of complex and limiting issues. His architecture always meets the requirements of functionality, formal elegance, feasibility and cost effectiveness, which usually are antithetical and hard to satisfy simultaneously.

\section{REFERENCES}

[1] De Seta, C., Architetti italiani del Novecento, Electa, GruppoMondadori: Napoli, pp. 49-74, 2006.

[2] Benevolo, L., Storia della architettura moderna, Laterza: Roma-Bari, pp 36-46, 1966.

[3] Istituto Centrale per la Demoetnoantropologia (IDEA), http://www.idea.mat. beniculturali.it (accessed 7 July 2014).

[4] Hellebois, A., Launoy, A., Pierre, C., De Lanève, M. \& Espion, B., 100-year-old Hennebique concrete, from composition to performance. Construction and Building Materials, 44, pp. 149-160, 2013. DOI: 10.1016/j.conbuildmat.2013.03.017.

[5] Associazione Italiana Tecnico Economica del Cemento (AITEC), http:// web.aitecweb. com/AREA ECONOMICA/VARIE/Avvento ed evoluzione del sistema Hennebique.pdf (accessed 19 July 2014). 
[6] Lista, G., Futurismo. Velocità e dinamismo espressivo. Finest Sa/Pierre Terrail Editions: Parigi, pp. 36-52, 2001.

[7] Caruso, L., Manifesti, proclami, interventi e documenti teorici del futurismo, 1909-1944. Spes-Salimbeni: Firenze, pp. 35-42,1980.

[8] Costanzo, M. \& De Propis, M., Sant' Elia e Boccioni le origini dell'architettura futurista, Mancosu: Roma, 2006.

[9] Augelli, F., Lo sviluppo e l'impiego dei prodotti ceramici in Italia nel periodo autarchico. Costruire in laterizio, 60, pp. 425-430, 1997.

[10] Sersale, R., I materiali ceramici ordinari e speciali, Casa Editrice Ambrosiana: Milano, pp. 27-29, 1975.

[11] Sollazzo, A., Così l'edilizia fascista si armò senza cemento. La Gazzetta del Mezzogiorno, 07(09), pp. 18-19, 2014.

[12] GURI, Gazzetta Ufficiale della Repubblica Italiana, Abrogation of Royal Decree-Law of 7 September 1939 n. 1326 prohibiting the use of reinforced concrete and iron in construction and in some other uses, Serie Generale, n.84, 11 Aprile, 1947.

[13] Castagnoli, U., Rubrica Tecnica: IV Mostra tecnico-artistica di materiali e forniture edili. Rassegna di Architettura, XI 15 Dicembre n.12, pp. 541-544, 1932.

[14] Minnucci, G., La litoceramica Italklinker. Architettura, Rivista del Sindacato Nazionale Fascista Architetti, XI Aprile, Fascicolo 4, 1933.

[15] Tentori, F., L`Architettura contemporánea. In dieci lezioni (dividendo per undici), Gamgemi Editore: Roma, pp. 47-57, 1999.

[16] Klatmagazine, http://www.klatmagazine.com/architecture/giovanni-muzio/45548 (accessed 11 November 2015).

[17] Lombardiabenicultutali, http://www.lombardiabeniculturali.it/architetture/schede/LMD8000303 (accessed 21 June 2015).

[18] ARTE FASCISTA, http://www.artefascita.it (accessed 12 November 2015).

[19] De Simone, R., Il Razionalismo nell architettura italiana del primo novecento, Giuseppe Laterza \& F.1li Spa. SEDIT: Roma-Bari, pp. 118-141, 2011.

[20] Zevi, B., Giuseppe Terragni, Serie Architettura n. 7, Introduzione, Nicola Zanichelli Ed. S.p.A.: Bologna, pp. 10-16, 2006.

[21] http://www.portaledicomo.it Monumenti (accessed 09 September 2014).

[22] Pampaloni, G. \& Verdone, M., I futuristi italiani. Immagini, biografie,notizie. Le Lettere: Firenze, p. 23, 1977.

[23] Nervi, P.L., Costruire correttamente. Caratteristiche e possibilità delle strutture cementizie armate, Ulrico Hoepli: Milano, pp. 89-112, 1965. 